\title{
The incidence of alpha-thalassemia in Setif, Algeria
}

\section{Cezayir, Setifte alfa-talasemi sıklı̆̆}

\author{
Ayşenur Öztürk ${ }^{1}$, Bakhouche Houcher ${ }^{2}$, Nejat Akar ${ }^{1}$ \\ 1Department of Pediatric Genetics, Ankara University Faculty of Medicine, Ankara, Turkey \\ 2Department of Biology, Faculty of Sciences, University of Setif, Setif, Algeria
}

\section{To the E ditor,}

Thalassemias are hereditary anemia syndromes occurring due to erroneous producing of globin chain of hemoglobin. Thalassemia syndromes are named according to the type of the affected globin chain. The most common types of thalassemia are alpha thalassemia and beta thalassemia. In $\alpha$-thalassemia, $\alpha$-globin chain production is either by decreased or completely disappeared. The gene encoding the $\alpha$-globin chain localized on the short arm of chromosome 16 (16p13.3). In normal adults, alpha-globin genes are found in four copies. One copy of each $\alpha 1$ and $\alpha 2$ genes are located in cis position on DNA chain [1]. The alpha-globin gene deletions constitute $80-90 \%$ of the mutations. The carriers for $\alpha$-thalassemia have either three $(-\alpha / \alpha \alpha)$ or two $(--/ \alpha \alpha) \alpha$ genes. The most common clinical form is $\mathrm{HbH}$ disease and the most frequently encountered genotype of $\mathrm{Hb} \mathrm{H}$ disease is --/- $\alpha$ and rarely $\mathrm{Hb}$ Bart's hydrops fetalis in which all four genes are deleted. In Mediterranean region, $-\alpha^{3.7}$, $-\alpha^{4.2},--$ MED and $-\alpha^{20.5}$ deletions are the most prevalent molecular defects [2].

The mutations of $\alpha$-thalassemia have been reported as $-\alpha^{3.7},--\mathrm{MED},-\alpha^{20.5}$ and $\alpha^{\mathrm{Hph} \mathrm{I}} \alpha$ in Algerian population $[3,4]$ and $-\alpha^{3.7}$ was determined as the most frequent haplotype [3]. In a recent study, in addition to these mutations, $\alpha^{\text {Nco I }} \alpha$ was shown and $\alpha$-thal allele frequency found $4.6 \%$, with the $-\alpha^{3.7}$ haplotype being $2.9 \%$ in randomly selected blood donors in Algiers, the capital city of Algeria which is located at the Mediterranean Sea coast [5].

On the other hand, Setif province is located in the high plateau of north-east Algeria, approximately 100 kilometers from the Mediterranean Sea. This is the first study for the molecular characterization of the $\alpha$-thal gene frequency in healthy individuals from the Setif region.

The study group included 153 unrelated healthy individuals from Setif. Informed consent was obtained from all the participants. Blood samples were collected with EDTA-containing tubes, transferred and DNA was extracted from peripheral blood leukocytes according to phenol-chloroform method. Genomic DNA was tested for the $-\alpha^{3.7}$, $-\alpha^{4.2},-$-MED and $-\alpha^{20.5}$ deletions using multiplex-polymerase chain reaction (PCR) according to described methods [6,7].

The prevalence of alpha thalassemia trait was found to be $6.5 \%$ in the study group. The molecular characterization of the $\alpha$-thal defects in these subjects revealed $-\alpha^{3.7}$ allele frequency as $3.3 \%$. We have not found any other individual of carrying 
alpha $4.2 \mathrm{del}$, MED or 20.5 deletions in our study group.

The frequency difference between the two regions can be explained by the location of the two cities. As Algiers is located at the Mediterranean Sea coast, it is expected to have high $\alpha$-thal frequency because of the probable malaria infection. This is not the case for Setif as it is located far from the coast.

\section{Conflict of Interest}

No author of this paper has a conflict of interest, including specific financial interests, relationships, and/or affiliations relevant to the subject matter or materials included in this manuscript.

\section{References}

1. Deisseroth A, Nienhuis A, Turner P, Velez R, Anderson WF, Ruddle F, Lawrence J, Creagan R, Kucherlapati R.
Localization of the human $\alpha$-globin structural gene to chromosome 16 in somatic cell hybrids by molecular hybridization assay. Cell 1977;12:205-18.

2. Kattamis AC, Camaschella C, Sivera P, Surrey S, Fortina P. Human alpha-thalassemia syndromes: detection of molecular defects. Am J Hematol 1996;53:81-91.

3. Henni T, Morlé F, Lopez B, Colonna P, Godet J. $\alpha$-Thalassemia haplotypes in the Algerian population. Hum Genet 1987;75:272-6.

4. Leclerc T, Guetarni D, Bernet A, Colonna P, Godet J, Morlé F. Identification of three different $\alpha$-thalassemic haplotypes: $-\alpha 3.7,(--) \mathrm{MED}, \alpha \mathrm{Hph} \mathrm{I} \alpha$ in the same Algerian family. Hum Mutat 1995;5:182-3.

5. Molecular basis of alpha-thalassemia in Algeria. Mesbah-Amroun H, Rouabhi F, Ducrocq R, Elion J. Hemoglobin. 2008;32:273-8.

6. Oron-Karni V, Filon D, Oppenheim A, Rund D. Rapid detection of the common Mediterranean alpha-globin deletions/rearrangements using PCR. Am J Hematol. 1998;58:306-10.

7. Tan AS, Quah TC, Low PS, Chong SS. A rapid and reliable 7-deletion multiplex polymerase chain reaction assay for alpha-thalassemia. Blood. 2001;98:250-1. 